\title{
Tegnologiese determinisme: kontoere van 'n konsep
}

\author{
Tom Lamey \\ Ferdinand Postma-Biblioteek \\ Potchefstroomse Universiteit vir $\mathrm{CHO}$ \\ POTCHEFSTROOM
}

\begin{abstract}
Technological determinism: contours of a concept

Technological determinism, which in essence is the concept meaning that 'technology determines history', has its roots in eighteenth-century Enlightenment. It has manifested itself against various political backgrounds as the idea of the devclopment of human power in overcoming nature and anti-revolutionary forces, as well as a view of technology as a method of political salvation. The approaches of various thinkers are categorized by Bimber as being either normative (corresponding to a soft determinism), nomological or one of unforseen consequences. During the wentieth century a number of writers (among them Ellul) have expounded pessimistic and even fatalistic views on the effects of technology. Ironically, they have thus done much to enhance the image of technology as a force in society.

Both those who view technology positively and those who are intensely sceptical about its influence accord it an active, even autonomous role in the development of society. However, a third view is both possible and imperative, namely that technology and its development are part of both our freedom and our responsibility, and that it must therefore be controlled and utilized as part of our stewardship of God's creation.
\end{abstract}

\section{Inleiding: terminologiese verheldering}

Soos die geval is met baie ander filosofiese stromings of opvattinge, is ook die tegnologiese determinisme stewig gevestig in sowel die werk van ernstige filosowe as in die opvattings van Jan Alleman. Mense wat nie sal droom om hulleself filosowe te noem nie (stellig selfs eksepsie sal neem aan so 'n betiteling) is maar alte geneig om 'n baie hoë waarde te heg aan die rol van die tegnologie in hulle eie lewe en die van die gemeenskap as 'n geheel. In die populêre pers word besonder baie aandag gegee aan nuwe tegnologiese ontwikkelinge en aan die effek wat dit op elkeen se lewenspatroon het. Dit is 'n moderne gemeenplaas dat die vinnige ontwikkelinge in die inligtings- en kommunikasietegnologie van die afgelope twee of drie dekades besig is om die gemeenskap te transforneer en om 
Tegnologiese determinisme: kontoere van $n$ konsep

selfs ' $n$ invloed uit te oefen op die wyse waarop politieke mag in die moderne staat toegedeel en uitgeoefen word.

Marx en Smith (1994:ix) verwys na hierdie algemene bewustheid van die rol van tegnologiese ontwikkeling as "tacit knowledge" en vestig verder die aandag op die wyse waarop tegnologiese artefakte die neiging het om as aktiewe onderwerpe in alledaagse taalgebruik te funksioneer, en daarmee as ' $t$ ware ' $n$ lewe van hul eie aan te neem. In hierdie verband is die feitlik magiese kragte wat dikwels aan "die rekenaar" toegeskryf word en die oorspanne verwagtinge wat daarvan gekoester word, ongetwyfeld ter sake. Ook die wyse waarop deesdae selfs in wetenskaplike kringe onkrities na die Internet gekyk word as die oplossing van allerlei inligtingsprobleme, getuig van hierdie neiging tot lewegewing (of dan ten minste die toeskrywing van invloed)

Oor die definisie van die begrip tegnologiese determinisme kan breed uitgewy word. Marx en Smith (1994.xiv) se poging tot 'n definisie daarvan verwys na die menslike geneigdheid om die tipe gemeenskap te skep wat aan die tegnologie genoeg mag gee om die geskiedenis in beweging te bring. Williams (1994:218) wys daarop dat al die verskillende variëteite van hierdie gedagterigting gereduseer kan word na drie woorde: "Technology determines history". Sowel Heilbroner as Bimber, aan wie se standpunte later meer uitvoerig aandag gegee word, onderskei tussen verskillende gestaltegewings van die tegnologiese determinisme.

Een van die probleme rondom die verskillende vorme van hierdie opvatting, en dus meteen ook met die oorweging daarvan, is dié van terminologie. Williams (1994:218-221) dui tereg aan dat nie eer van die kernkonsepte in hierdie verband sonder probleme is nie. Die inhoud van die term tegnologie het oor die jare dermate verbreed dat dit imperialistiese neigings vertoon. Die term deterministies soos dit meesal gebruik word, vooronderstel klaarblyklik die idee van 'n vooraf vrye individu, terwyl die begrip geskiedenis of histories as die dimensie van menslike bestaan waarbinne die tegnologiese determinisme dit voltrek, ook nie eenduidend en sonder sy probleme is nie. Daar is ' $n$ toenemende neiging in die moderne era om die geskiedenis te gaan herdefinieer as 'n rekord van sosioekonomiese vordering - 'n omskrywing wat die geskiedenis dus per definisie amper ' $n$ tegnologies-gedrewe proses maak.

Oor die verslawende effek van tegnologiese vordering op menslike opvattinge en op die gemeenskap het sulke uiteenlopende filosowe soos Popper en Radhakrishnan reeds die aandag gevestig (Cooper, 1995:7). Taute (aangehaal deur Schuurman, 1980:i) wys daarop dat vir baie moderne mense die enigste geloof nou dié in die wetenskap en tegnologie is, terwyl daardie selfde dinge vir baie ander die oorheersende vrees van hulle lewe geword het. Baie moderne denkers gebruik die wetenskap en tegnologie om die geskiedenis ondergeskik te 
maak en om dit te onderwerp aan menslike idees, maar die uitkoms is net die teenoorgestelde: die mens word die slaaf en nie die heerser van die tegnologie nie (Schuurman, 1980:2).

\section{Historiese wortels}

Die herkoms van die tegnologiese determinisme as begrip is stellig terug te voer na die leiers van die Verligting van die agtiende eeu (Smith, 1994:2). Die geskiedenis het in die denke van eksponente van die Verligting 'n deel geword van die domein van die triomferende mens. Ook het die tegnologiese determinisme die mens se onafhanklikheid van geestelike en natuurlike noodwendigheid só verklaar: "to affirm that technology drives history, is to deny that God does" (Williams, 1994:222). (In dié proses, sê Williams, is nie net God doodgemaak nie, maar ook die natuur.) Volgens Ellul (1980:69) is tegnologiese vooruitgang essensieel 'n manifestasie van menslike mag en 'n geleentheid vir die mens om homself te bewonder. Tegnologiese vooruitgang bring 'n grootskaalse transformasie van die gemeenskap teweeg: die gemeenskap beweeg van 'n hiërargiese in ' $n$ meer egalitariese rigting en die idee van besit en die aard van werk verander ook.

Die naam van Karl Marx word populêr met hierdie gedagterigting verbind, maar Ropohl (1983:86) wys tereg daarop dat baie van Marx se uitsprake waarop hierdie vertolking berus, eintlik polemiese oordrywing is en dat Marx in werklikheid 'n wederkerige verhouding tussen die tegnologie en die sosiale stelsel aanvaar het. Ook Bimber (1994:89-100) kom na 'n uitvoerige ontleding aan die hand van maatstawwe wat hy ontwikkel, tot die gevolgtrekking dat Marx geen tegnologiese deterninis was nie.

Die tegnologiese determinisme as revolusionêre opvatting predateer Marx inderwaarheid. In die denke van twee van die Franse vaders van die Verligting, te wete Turgot en Condorcet, figureer ontwikkeling in die vorm van vervoer en kommunikasie as die tegnologiese verowering van ruimte om daarmee die antirevolusionêre magte te oorkom, reeds besonder sterk (Williams, 1994:223225).

Ook in die ander groot produk van die agtiende-eeuse politiek, naamlik die Amerikaanse revolusie en die daaropvolgende republiek, is die spore van hierdie gedagtelyn merkbaar. Benjamin Franklin en Thomas Jefferson het albei in die meganiese tegnologie middele gesien om die ideaal van 'n voorspoedige Amerikaanse gemeenskap te bereik, terwyl Coxe, 'n ander Amerikaner, dit as 'n metode van politieke redding gesien het daarin dat ekonomiese onafhanklikheid die nuutgevonde politieke onafhanklikheid moes beskerm. "From the start, technological determinisin proved highly compatible with the search for political order" (Smith, 1994:4-5). 
Daar is reeds verwys na die wyse waarop die onkritiese aanvaarding van die (meesal voordelige) effekte van tegnologiese ontwikkeling verskeie opvattings oor 'n breë spektrum steeds ten grondslag lê. Voorbeelde uit die minder en meer resente literatuur van die werksaamheid van sodanige sienings, selfs waar dit nie werk met eksplisiete definisies van tegnologie of kousale verbande nie, sou daarom vermenigvuldig kon word. Die sosioloog, Daniel Bell, het met sy konsep van die post-industriële gemeenskap een van die onmiddellike voorlopers van die huidige populêre konsep van die inligtingsamelewing geword. ${ }^{1}$ Bell grond sy opvatting van die ontwikkeling van 'n radikaal nuwe fase in die ontwikkelingsgeskiedenis ${ }^{2}$ heel direk op die wyse waarop tegnologiese ontwikkelinge steeds groter industrialisasie en stygende produktiwiteit moontlik maak. Hierdie prosesse lei op hul beurt tot die toenemende daarstelling van welvaart vir die lewer van nuwe dienste (Webster, 1995:34-35).

In Suid-Afrika was die industrialis en denker, Hendrik van der Bijl, 'n meer as net indirekte verteenwoordiger van soortgelyke denkrigtings. Van Niekerk en Van der Walt het aangetoon (1996:301-303) hoe Van der Bijl se benadering van gemeenskapsontwikkeling gebaseer was op sciëntistiese uitgangspunte. Onvermydelik het die hoogskatting van die wetenskap vir hom ook gelei tot oordrewe verwagtinge van tegnologiese en industriële ontwikkeling. Hy het niks minder verwag nie as dat industriële ontwikkeling en die gevolglike materiële welvaart sou bydra tot nasievorming en die verdwyning van rasseprobleme (Van Niekerk \& Van der Walt, 1996:302-303).

Ten spyte van die voortduur tot vandag toe van die aanvanklike optimisme oor die rol van tegnologiese ontwikkeling, het daar veral in die twintigste eeu beskouings met uitgesproke pessimistiese en selfs fatalistiese ondertone na vore gekom. Hierdie beskouings het gegroei tot 'n sterk intellektuele tradisie in die Westerse denke van die twintigste eeu - selfs die moderne ekologisme het sy wortels in dié tradisie gehad (Ropohl, 1983:86). Andersyds, meer op formele vlak, is die ontwikkeling van die konsep en die groter aandag wat daaraan gegee word, ook die produk van 'n modeme historiologie wat net soveel aandag gee aan agtergrondsfaktore as aan die historiese feite wat hulle onmiddellik voordoen (Heilbroner, 1994b:70).

1 Bell het in sy latere geskrifte self dic term "inligtingsamelewing" begin gebruik (Webster, 1995 36)

2 Hierdie nuwe fase is later deur Toffler gepopularisecr as "the third wave". 


\section{Robert IIeilbroner se sistematiese ontleding}

Die historikus/sosioloog, Robert Heilbroner, was met sy klassieke artikel "Do machines make history?" wat in 1967 verskyn het ${ }^{3}$, een van die eerstes om omvattend akademies aandag te gee aan die konsep van tegnologiese deterninisme. Dit gaan vir Heilbroner oor die sosio-ekonomiese invloede van die tegnologie. Na aanleiding van die veelaangehaalde stelling van Karl Marx, "The hand-mill gives you society with the feudal lord; the steam-mill, society with the industrial capitalist"4, hou Heilbroner hom besonderlik besig met twee vrae in hierdie verband. Ten eerste besin hy oor die vraag waarom die tegnologie op 'n besondere wyse ontwikkel het en tweedens oor die wyse waarop produksiemetodes die superstruktuur van sosiale en politieke verhoudinge beinvloed

Vir die konsep van 'n gedetermineerde volgorde in die ontwikkeling van die tegnologie meen hy om drie bewyse te vind (1994b:56-57), naamlik die gelyktydigheid van uitvindings, die afwesigheid van tegnologiese spronge, en die voorspelbaarheid van tegnologiese ontwikkeling. Hy voeg daarby twee verdere dieperliggende redes vir die feit dat die tegnologie ' $n$ gestruktureerde geskiedenis behoort te vertoon, te wete die vlak van gekumuleerde kennis as 'n beperking op tegnologiese ontwikkeling, sowel as dit wat hy noem die "material competence of the age" (1994a:58), oftewel die vlak van tegniese kundigheid. Daarbenewens is sodanige ontwikkeling ook afhanklik van arbeidsverdeling, die spesialiseringsvlak van die industrie en die akkumulasie van kapitaal.

Ten opsigte van die vraag na die invloed van tegnologiese ontwikkeling op die sosiale verhouding binne die gemeenskap vind Heilbroner twee aspekte wat daardie invloed uitmaak. Sosıale verhoudinge word naamlik beinvloed deur die samestelling van die arbeidsmag wat wissel na gelang van die tegnologiese middele wat bedien moet word, asook die hiërargiese organisasie van werk wat op sy beurt beinvloed word deur die verskillende vlakke van toesig en koordinasie wat deur verskillende tegnologieë benodig word.

Heilbroner (1994a:61-63) beklemtoon egter dat hy bepaalde voorbehoude het wat hom 'n minder reglynige verhouding tussen tegnologie en sosiale verwantskappe laat stel as wat die geval by Marx is. Tegnologiese vooruitgang is self ' $n$ sosiale aktiwiteit wat bepaal word deur die aard en vlak van sosiale organisasie binne 'n gemeenskap. Eweneens is die gang van tegnologiese vordering beïnvloedbaar deur sosiale druk en moet tegnologiese verandering versoenbaar wees met bestaande sosiale omstandighede. Dit bring hom daarby om eerder 'n 'sagte'

3 Die heropname van hicrdic artikel in 'n versamelwerk word in dic bronnelys aangedui

4 Aanhaling uit The poverty of philosophy - opgencem in Heilbroner (1994a:54) 
Tegnologiese determinisme: kontoere van 'n konsep

determinisme te aanvaar, alhoewel die voorbehoude wat hy het, eerder die basiese uitgangspunt oor tegnologiese invloed kwalifiseer as dit weerspreek.

As hy daarna aandag gee aan die bemiddelende rol van tegnologie in die moderne Westerse gemeenskap (1994a:63-65), vind hy dit daarin dat die opkoms van kapitalisme 'n belangrike stimulus vir die ontwikkeling van produksietegnologie geskep het. Verder het die uitbreiding van tegnologie in die markekonomie iets van 'n outomatiese vorm aangeneem deur die werking van markkragte en die heersende ideologie van laissez-faire. Ook het wetenskaplike vordering 'n belangrike stukrag aan die ontwikkeling van die tegnologie gegee. Tegnologiese determinisme is dus volgens Heilbroner ' $n$ besondere probleem van 'n bepaalde historiese epog waarin die kragte van tegnologiese verandering losgelaat is, sonder dat noemenswaardige maatreëls vir die beheer daarvan ontwikkel is.

Heilbroner kom in 1994, na sy aftrede, terug op sy aanvanklike opvattings oor die tegnologiese determinisme, maar bevestig grootliks sy aanvanklike sienings. Vir hom maak masjiene nog steeds geskiedenis deur die materiële omstandighede van mense te verander. Hy voeg egter twee belangrike waarnemings toe tot sy aanvanklik uitwerk van die begrip.

Die eerste hiervan is die konsep van die ekonomie as kragveld ("force field" Heilbroner, 1994b:71), as die meganisme waardeur veranderinge in die tegnologie invloed uitoefen op die organisasie van die sosiale orde (1994b:7273). Hierdie invloed word onder andere uitgeoefen deur middel van die prysmeganisme en die beginsel van die maksimalisering van voordeel

Amper meer belangrik as hierdie byvoeging van Heilbroner (hy het per slot van sake reeds in sy oorspronklike artikel aandag gegee aan die spesifiek kapitalisties-ekonomiese aspekte) is sy beklemtoning dat tegnologiese determinisme nie as 'n logika van besluitneming gehanteer moet word nie, maar as 'n heuristiese metode by die ondersoek en interpretasie van sosio-ekonomiese gebeure. Hierdie beklemtoning berus op die uitgangspunt dat menslike gedrag nie willekeurig of chaoties is nie, maar bepaal word deur ontontkenbare reëlmatighede. Die kern hiervan is wat hy noem die "acquisitive mindset" as 'n algemene motief vir optrede (1994b:74). Soos in sy eerste artikel, kom Heilbroner opnuut uit by 'n sogenaamde 'sagte' determinisme.

\section{4. 'n Tipologie: normatief, nomologies, onvoorsien}

Dit is hierdie herhaalde voorkeur van Heilbroner vir 'n sagte determinisme wat dit so onbegryplik maak dat Bimber (1994) juis Heilbroner se sienings (weliswaar slegs aan die hand van die eerste artikel) as die beste verteenwoordiging beskou van wat hy bestempel as 'n nomologiese interpretasie van die tegnologie. 
Terwyl daar meermale in die literatuur (by Heilbroner self ook, soos hierbo aangedui) verwysings is na verskillende vorme van tegnologiese determinisme, is die artikel van Bimber die enigste waarin eksplisiet gepoog word om 'n tipologie van tegnologies-deterministiese beskouings uit te werk. (Verskillende vorme van tegnologiese determinisme word geidentifiseer op grond van die mate waarop ander beinvloedende of medierende faktore ook verdiskonteer word.)

Volgens Bimber (1994:80) is die langdurige bestaan van die begrip tegnologiese determinisme hoofsaaklik daaraan toe te skryf dat dit meer as een verskynsel beskryf en dat hierdie feit ' $n$ belangrike bydrae lewer tot verskillende debatte of dit werklik die ontplooiing van die geskiedenis korrek beskryf. Veral oor die vraag of Karl Marx werklik 'n tegnologiese determinis was, is daar duidelik twee groepe denkers met teenoorstaande menings te identifiseer.

Drie verskillende groepe benaderings word deur Bimber onderskei, naamlik die normatiewe en die nomologiese benadering en dié van onvoorsiene gevolge.

\section{- Die normatiewe benadering}

Die normatiewe benadering word deur Bimber as die mins presiese van die drie beskryf, omdat dit volgens hom op menslike benaderings berus. Hy verwys hier na veral Habermas as ' $n$ verteenwoordiger van hierdie denkrigting. Habermas het dit veral oor die te groot klem wat op produktiwiteit en doeltreffendheid gelê word. Ook beklemtoon Habermas die feit dat die tegnologie outonoom word as die norme waarvolgens dit bedryf word, verwyder word uit die politieke en etiese gesprek. Die tegnologie kan ook outonoom word as die genoemde oogmerke surrogate word vir die debat oor waardes (Bimber, 1994:81-92). Benewens Habermas beskou hy ook vir Jacques Ellul, Lewis Mumford, Herbert Marcuse en Winner as verteenwoordigers van hierdie subrigting.

\section{- Die nomologiese benadering}

As gesê kan word dat die verteenwoordigers van die normatiewe benadering tot 'n groot mate ooreenstem met dié wat Schuurman (1972) as 'transendentalistiese' denkers tipeer, is die ooreenstemming van die nomologiese benadering met Schuurman se positivistiese denkers nie so vanselfsprekend nie. Dit gaan by die nomologiese naamlik nie net oor die positiewe houding oor tegnologiese ontwikkeling nie, maar ook oor ' $n$ besliste opvatting dat tegnologiese ontwikkeling berus op wette van die natuur, eerder as op sosiale norme. Die tegnologie self oefen ' $n$ invloed in die geskiedenis uit en in die lig van die huidige stand van die tegnologie asook die stand in die verlede, is daar net een pad vir sosiale verandering (Bimber, 1994:83). Sosiale strukture ontwikkel in aanpassing by tegnologiese verandering omdat die volgens 'n ingeboude logika ontwikkel en sosiale aanpassing afdwing. Volgens Bimber is die nomologiese benadering se sienings kultuur-onafhanklik en maak dit ontologiese aansprake - in teenstelling 
Tegnologiese determinisme: kontore van 'n konsep

met die normatiewe benadering se voorsiening vir die invloed van menslike kultuur en houdings.

(Daar is reeds melding gemaak van Bimber (1994:84) se enigsins vreemde klassifikasie van Heilbroner as die bekendste verteenwoordiger van hierdie benadering. Bimber grond sy klassifikasie klaarblyklik op Heilbroner se stellings oor die noodwendigheid van tegnologiese ontwikkeling binne bepaalde tyds- en geografiese omstandighede, maar ignoreer baie gerieflik die kwalifikasies wat Heilbroner reeds in die eerste artikel daaroor maak.)

- Die benadering van onvoorsiene gevolge

Die benadering wat Bimber bestempel as dié van onvoorsiene gevolge kom volgens hom (1994:85) voort uit die waarneming van die onsekerheid en onbeheerbaarheid van die gevolge van optredes. Tegnologiese ontwikkeling het dus 'n rol buite menslike beheer om en daar is terselfdertyd ook 'n afwesigheid van onontkombare natuur- of tegnologiese wette wat die ontwikkeling daarvan rig.

Vir die beoordeling van die verskillende benaderings doen Bimber (1994:86) op spoor van Cohen twee maatstawwe of toetse aan die hand. 'n Opvatting of teorie wat aanspraak maak daarop om tegnologiese determinisme weer te gee, word soos volg getipeer:

- Die teorie moet in die eerste plek deterministies wees daarin dat dit fisiese en biologiese faktore sien as bepalend vir die geskiedenis en nie die menslike wil nie.

- In die tweede plek moet so 'n teorie eerder tegnologies-georiënteerd as ekonomies, polities of wat ook al wees. Die tegnologie moet naamlik die medium wees waardeur fisiese wette menslike gebeurtenisse bepaal.

Op grond van hierdie twee maatstawwe reken Bimber om die moontlikheid van harde en sagte vorme van tegnologiese deterninisme uit te skakel. Ook die insluiting van sosiale organisasie as faktor in die deurwerking van tegnologiese ontwikkeling se gevolge word daarmee uitgeskakel: volgens Bimber veroorsaak die insluiting van sosiale organisasie by die definisie van die tegnologie dat oorsaak en gevolg deurmekaarloop (Bimber, 1994:88).

Dit volg dan ook eintlik logies dat slegs die nomologiese benadering die toetse wat Bimber aanlê, kan slaag. Die normatiewe benadering slaag nie een van die toetse nie en word daarvan beskuldig dat dit die tegnologiese determinisme dekonstrueer in 'n kulturele verskynsel. Met onvoorsiene gevolge word ook korte mette gemaak: Bimber sien dit eintlik as indeterminisme eerder as determinisme. Hy doen aan die hand dat daar 'n ander noemer vir hierdie twee 
Tom Larney

benaderings gesoek word en doen die begrip tegnologiese momentum aan die hand.

Hughes (1994) gee in sy artikel die begrip tegnologiese momentum aan die hand as 'n alternatief vir sowel tegnologiese determinisme as vir sosiale konstruksie. Volgens hom het albei hierdie begrippe op 'n stadium 'n alternatief of korrektief gebied vir die gebrek aan aandag wat in die voorafgaande tydperk aan die verrekening van 'n bepaalde faktor gegee is. Tans gaan hierdie terme egter mank aan 'n vermoë om die kompleksiteit van tegnologiese verandering te omvat

In sy poging om sy verskil van mening met sowel die tegnologiese deterministe as die sosiale konstruktiviste te regverdig, maak Hughes hom myns insiens skuldig aan 'n oorvereenvoudiging van standpunte. Alhoewel hy sommige van Ellul se standpunte toeskryf aan "moments of simplification" (Hughes, 1994:103), wend hy geen poging aan om die kompleksiteit daarvan te verreken nie. Hy sê dat die begrip tegnologiese momentum probeer om 'n meer komplekse, plooibare, tydafhanklike en oortuigende verklaring van tegnologiese verandering te gee, en kom op die ou end tot die gevolgtrekking (Hughes, 1994:112) dat dit êrens tussen die pole van die ander twee begrippe lê. 'n Tegnologiese stelsel kan sowel die oorsaak as die gevolg van sosiale omstandighede wees. Namate stelsels groter en meer kompleks word, neig dit om 'n groter invloed op die gemeenskap uit te oefen en minder daardeur beinvloed te word. Die sosiale konstruktiviste het dus 'n sleutel tot die verstaan van jonger stelsels en die tegnologiese deterministe tot die verstaan van ouer stelsels.

\section{Pessimistiese en fatalistiese beskouings}

Daar is reeds vroeër melding gemaak van Ropohl se stelling dat die fatalistiese beskouings oor die rol van die tegnologie gegroei het tot 'n sterk intellektuele tradisie in die Westerse denke van die twintigste eeu. Hiervoor sou verskeie redes waarskynlik geidentifiseer kon word, sowel in die veld van die ontwikkeling van filosofiese stelsels as in die politieke ontwikkeling wat die eeu gekenmerk het. Die belangrikste aanleiding moet egter sekerlik gesoek word in die mate van volwassenheid wat die tegnologie bereik het en die wyse waarop die tentakels daarvan haas elke aspek van die mens se lewe begin omvat het. Dit was daarom waarskynlik iets van 'n historiese noodwendigheid dat skerp kritiese en pessimistiese sienings oor die aard en rol van die tegnologie na vore sou moes tree.

Alhoewel die lys van denkers wat hulle in hierdie tradisie bevind het en steeds bevind, waarskynlik taamlik lank sou wees, reken Smith (1994:28) veral drie as behorende daartoe, naamlik Lewis Mumford, Jacques Ellul en Langdon Winner. 


\section{- Lewis Mumford}

Die Amerikaner Mumford, wat bekendheid verwerf het vir sy werk op 'n wye aantal terreine, was aanvanklik heel positief ingestel oor die moontlikhede van die tegnologie. Teen die dertigerjare het hy nog die hoop gekoester dat die wetenskapsgebaseerde tegnologie van die twintigste eeu die verskille tussen die masjien en die menslike gees sou kon bylê deur die ontwikkeling van 'n 'organiese meganisme' wat die mensdom sy volle potensiaal sou kon laat bereik (Smith, 1994:28). Hierdie optimisme slaan teen die vyftigerjare oor in 'n pessimisme wat dit veral het oor die mite van die masjien wat die mens laat afstuur op 'n finale totalitêre struktuur, sowel as die ontmenslikte organisasies 'n 'megamasjien', noem hy dit (Smith, 1994:29) - wat hierdeur geskep word

\section{- Jacques Ellul}

In die denke van die Franse skrywer, Jacques Ellul, kry 'n mens iets van dieselfde tema van ontmensliking en tegnologiese outonomiteit terug. Omdat Ellul ' $n$ denker is wat oor 'n lang tydperk verskillende werke oor 'n verskeidenheid vakgebiede die lig laat sien het, en homself ook nie daarbo verhewe geag het om van mening te verander nie, is die gevaar groot dat, op dieselfde wyse as wat Bimber hierbo met Heilbroner omgegaan het, skrywers Ellul se uitsprake baie selektief kan aanwend. Desnieteenstaande moet hy gereken word onder die belangrikste skeptici oor die ontwikkeling van die tegnologie

'n Belangrike waarskuwende tema in Ellul se werk is die gedagte dat die tegnologie outonoom geword het en dat geen menslike aktiwiteit die imperatief daarvan kan ontsnap nie. Volgens Ellul het die tegnologie die milieu geword waarin van die mens verwag word om te bestaan (Smith, 1994:30). Die tegnologie word as 't ware 'n nuwe omgewing waarin die mens hom bevind omdat die ou omgewing opgehou het om een te wees as gevolg van die vernietiging van die natuur en sy hulpbronne (Ellul, 1980:44). Die ontwikkeling van die tegnologie, waardeur ' $n$ vereenvoudiging en reduksie van die hele werklikheid teweeggebring word, omvat nie net tegnologiese artefakte nie, maar ook organisasiemetodes, bestuurspraktyke en 'n inherent meganistiese denkwyse (Ellul, 1980:44-45). Die ontwikkeling van die tegnologie bring 'n grootskaalse groei in die staat se funksies en al meer sentralisasie mee, maar ironies genoeg het die gewone burger en selfs die politikus al minder mag (Ellul, 1980:55-56). (Interessant genoeg is dit byna dieselfde waarneming wat Stoker (1969:30) maak: die hoogs gespesialiseerde leiding wat deur tegnologiese ontwikkeling teweeggebring word, kan lei tot die vorming van 'n elite-oligargie, met die konsentrasie van al meer mag in die hande van al hoe minder mense.)

Dit is maklik om uit Ellul se werke heelwat meer vreesaanjaende uitsprake oor die tegnologie aan te haal. Hy gebruik sy uitsprake, sê hy, as 'n diagnose van die situasie en 'n oproep tot die mensdom om wakker te word (hy beskou dit as 
moontlik, maar nie waarskynlik nie), al weet hyself nie wat die oplossing is nie. Ewe belangrik is egter om te let op sy uitspraak dat hy nie die tegnologie as die enigste bepalende faktor sien nie (Ellul, 1980:66-67). Inderwaarheıd distansieer hy hom eksplisiet van die skrywer, Alvin Toffler, se siening van totale en konstante verandering wat deur die tegnologie teweeggebring word.

\section{- Langdon Winner}

Langdon Winner deel nie heeltemal Ellul se siening van die tegnologie as 'n outonome en rasionele allesoorheersende mag nie. Hy is eerder bekommerd oor die wyse waarop mense kragtige veranderinge in die wêreld teweegbring sonder inagneming van die gevolge daarvan. Dis menslike slaapwandelary, eerder as enige inherente tegnologiese imperatief, wat groot tegnologiese sisteme toelaat om die reels vir die menslike bestaan te formuleer (Smith, 1994:32). Die oplossing hiervoor is groter politieke beheer oor die tegnologie, wat volgens hom self inherent 'n politieke verskynsel is.

\section{Reformatoriese beskouings}

Daar is ' $n$ bepaalde ironie in die stellings wat denkers soos Mumford, Ellul en Winner oor die tegnologie maak: met hulle waarskuwings oor die mag en outonomiteit van die tegnologie het hulle waarskynlik meer gedoen om aan die tegnologie ' $n$ invloed en werksaamheid toe te ken as wat selfs die mees entoesiastiese propagandiste daarvoor sou kon doen (Smith, 1994:34). Alhoewel Ellul sy gedagtes self bestempel as 'n waarskuwing en daar by Winner 'n sterk voorkeur is vir politieke beheer van tegnologiese ontwikkeling, is daar tog oor die algemeen by hierdie denkers min op te merk van sistematiese alternatiewe vir die beheer van die tegnologie. Aan pessismisme is daar geen tekort nie, maar die verlossende woord ontbreek.

Hierdie oordeel is juis Schuurman (1980:1) se kritiek op Ellul en sy medestanders, naamlik dat hulle geskrifte onbevredigend is daarin dat hulle die probleme van die moderne tegnologie sien as te swaar vir die mens om te dra en as Christene dit bowendien sien as 'n outonome, demoniese mag. Daarmee word geen ruimte gelaat vir 'n perspektief van verlossing nie. Hy verwyt Ellul dit dat hy in sy konsentrasie op die gewaande outonomie van die tegnologie die ware wortel van die probleem, naamlik die opvatting van en strewe na menslike outonomie, buite rekening laat (Schuurman, 1980:3).

Dat beskouings oor en die hantering van die tegnologie ten diepste 'n lewensbeskoulike kwessie is, word bevestig deur Stoker (1969:20) as hy sê dat die hantering van die vryheidskrisis waarin die tegniek met sy mag oor die natuur die mens laat beland, in ' $n$ fundamentele sin deur onder andere religieuse oortuigings medebepaal word. Die tegniek self kan geen lewensbeskouing voortbring nie, maar dit is juis laasgenoemde wat die mens se uitkyk op die tegniek bepaal. Die 
Tegnologiese determinisme: kontoere van 'n konsep

sekularisme van die moderne tegniek kan volgens Stoker (1969:32) juis die nood van 'n era wees.

Watter komponente van 'n reformatoriese beskouing van die tegnologie is van belang om die regte perspektief op die plek daarvan in die mens se lewe te handhaaf? Vir Stoker $(1969: 24)$ is die tegnologie deel van die mens se vryheid, maar ook van sy verantwoordelikheid. Die kenmerke van die tegniek is dié van mag en nut, dus van middele en niks meer nie. 'n Voorwaarde vir die vryheid van tegniek is dat die mens 'heer van die tegniek' bly. Afhanklikheid van die tegniek beteken nie onvryheid nie, maar juis die ontplooiing van 'n nuwe tipe vryheid (Stoker, 1969:25). Die mens moet die spannings tussen die tegniek en die mens oorwin en hy moet die verdere ontplooiing van hierdie magsmiddele wat aan hom gegee is, aandurf (Stoker, 1969:28).

Hierdie selfde motief van die beheer oor en die ontplooiing van die tegnologie word deur Schuurman behandel. Vir hom (Schuurman, 1980:2) is die tegnologie nie 'n outonome mag nie, omdat dit van buite af deur mense gerig word. Die ontplooing van die tegnologie is deel van die mens se kultuuropdrag. Die gevolge van die sondeval vind ons in die tirannieke en gulsige gebruik van die mens se mag oor die natuur (1980:4). As die rigting van die kultuur in ooreenstemming met die mens se kultuuropdrag, verlossing en ontwikkeling moet wees, moet die basiese rigtende motief daarvan verander (1980:13). Die feit dat die tegnologie eerste in die lyn van Kain ontwikkel het - soos hy dit noem - is geneig om baie Christene negatief daarteenoor te stem. Daar is egter in die Skrif ook baie kontra-voorbeelde teenwoordig, waarvan Noag se bou van die ark een is (1980:9). Schuurman (1972:358) pleit vir 'n perspektief waarin die verantwoordelike sinontsluiting van die tegnologie in die regte lig gesien word. So 'n perspektief moet gestel word teenoor die ombuiging van die sinontsluiting deur wat hy die positiviste noem en die gelate afwagting van die kultuurpessimiste, waarvan die transendentaliste deel is. Die moderne tegnologie moet 'n aanpasbare en ekologies-verantwoordelike een wees, en waar nodig, moet die herstel van die omgewing die doel daarvan wees (Schuurman, 1995:95).

\section{Ten slotte}

Word die verskillende verteenwoordigers van die tegnologiese determinisme in oënskou geneem, is dit duidelik dat dit geen monolitiese gedagterigting is nie. Om die waarheid te sê, is die verskille nie altyd net een van graad nie, maar selfs meer dieperliggend. Aan die een kant vind 'n mens iemand soos Bimber, wat dit klaarblyklik noodsaaklik ag om die tegnologiese determinisme as teoretiese konsep duidelik af te baken en metodologies probeer om bepaalde maatstawwe vir die identifisering en kartering daarvoor aan te lê. Hierdie poging lei egter skipbreuk omdat enige sodanige strakke aanlê van kriteria daarin faal om sowel die kontinue aard van die ryk verskeidenheid opvattings oor die saak te verreken 
as om 'n sinvolle alternatief aan die hand te doen. In Heilbroner het ons te doen met ' $n$ denker wat pertinent histories-bepaalde bewyse poog te vind om die onafwendbaarheid van bepaalde tegnologiese ontwikkelings en die invloed daarvan te konstateer. Aan die ander kant van die spektrum kry ons daardie denkers wat op bepaalde normatiewe gronde baie ernstige probleme het met die invloed wat die onbeheerde ontwikkeling van die tegnologie na hulle mening op die gemeenskap het.

Daar is dus klaarblyklik probleme om die verskillende gedagterigtings oor hierdie komplekse saak op ' $n$ enkele spektrum te plaas of te beoordeel. Miskien is die plasing daarvan op die ou end egter ' $n$ bloot binêre keuse: ten diepste gaan dit vir al die denkers wat hier aan die orde gestel is, eksplisiet of implisiet oor die plek van die tegnologie in die verlossing van die mens. Die positiviste en transendentaliste (om Schuurman se terne te leen, al is die beoordeling nie noodwendig van toepassing, of net van toepassing, op dié wat hy bespreek nie) het die volgende in gemeen: albei groepe ken aan die tegnologie 'n kardinale en aktiewe rol toe, sy dit as die bewerker van die heil van die mens of in die tegnologie se outonomiteit as bewerker van die mens se ondergang.

Daarteenoor staan die enigste visie wat die mens verlos van die monster wat hy self geskep het en wat nou aan sy beheer ontsnap het. Alleen die uitsig op die tegnologie as die ontplooiing van die potensiaal wat God vir die mens in die skepping geplaas het, kan die mens bevry van 'n gevoel van onmag wat nooit sal ophou groei solank die tegnologie ontwikkel nie. Ook die tegnologie moet gesien word as deel van die skepping wat sug as gevolg van die sondeval (Rom. 8:22) en as uiteindelike mede-objek van die verlossende werk van Jesus Christus. Dit is die uitsig - nie op die tegniek as die verlosser of op die mens as die onverlosbare nie - maar op die tegniek as middel in die hand van die mens waarin nóg die mens, nóg die tegnologie, maar Jesus Christus as die vleesgeworde Woord van God, die hoeksteen van die geskiedenis is.

\section{Bronnelys}

BIMBER, B 1994 Three faces of technological determinism. (In Marx, L. \& Smith, M R eds Does technology drive history? The dilemma of technological determinism Cambridge, Mass : MIT Press. p 79-100.)

COOPER, D.E. 1995. Technology: liberation or enslavement? (In Fellows, R. ed Philosophy and technology. Cambridge : University Press. p. 7-18.)

ELLUL, J. 1980 The technological system New York: Continuum. 362p

HEILBRONER, R L 1994a. Do machines make history? (In Marx, L. \& Smith, M R eds Does technology drive history? The dilemma of technological determinism Cambridge, Mass. : MIT Press. p. 53-65.)

HEILBRONER, R L. 1994b Technological determinism revisited (In Marx, L \& Smith M R. eds Does technology drive history? The dilemma of technological determinism Cambridge, Mass. : MIT Press. p 67-78.) 
HUGHES, T P. 1994 Technological momentum. (In Marx, L. \& Smith, M R. eds Does technology drive history? The dilemma of technological determinism. Cambridge, Mass : MIT Press. p. 101-113.)

MARX, L \& SMITH, M R 1994. Introduction. (In Marx, L. \& Smith, MR. eds. Does technology drive history? The dilemma of technological determinism. Cambridge, Mass : MIT Press. p. ix-xv.)

ROPOHL, G 1983. A critique of technological determinism (In Durbin, P.T \& Rapp, F. eds. Philosophy and technology Dordrecht : Reidel. p 83-96.)

SCHUURMAN, E. 1972. Techniek en toekomst: confrontatie met wijsgerige beschouwingen Assen : Van Gorcum. 568p.

SCHUURMAN, E 1980. Technology in Christian-philosophical perspective Potchefstroom : PU vir CHO $17 \mathrm{p}$.

SCHUURMAN, E. 1995 Perspectives on technology and culture. Potchefstroom : PU vir CHO. $164 p$.

SMITH, M R. 1994 Technological determinism in American culture. (In Marx, L \& Smith, M R. eds. Does technology drive history? The dilemma of technological determinism. Cambridge, Mass. : MIT Press p. 1-35.)

STOKER, H.G. 1969 Mens en tegniek vandag (In Kotzee, A.L. et al. Mens en tegniek. Pretoria : Van Schaik. p 20-34)

VAN NIEKERK, R \& VAN DER WALT, M.F. 1996. Dr. H.J van der Bijl se filosofiese denkraamwerk - 'n histories-filosofiese oorsig. Koers, 61(3):291-310.

WEBSTER, F. 1995. Theories of the information society London: Routledge. 257p.

WILLIAMS, Rosalind. 1994. The political and feminist dimensions of technological determinism. (In Marx, L. \& Smith, M R. eds Does technology drive history? The dilemma of technological determinism. Cambridge, Mass. : MIT Press. p. 217-235.) 